\title{
Tillage systems and nitrogen timings effect on growth, stay green and grain quality in maize (Zea mays $\mathrm{L}$.)
}

\author{
Sistemas de preparo do solo e efeitos do tempo de nitrogênio no \\ crescimento, manutenção da qualidade de grãos e verde no milho \\ (Zea mays L.)
}

\author{
Allah Wasaya ${ }^{1 *}$; Muhammad Tahir²; Tauqeer Ahmad Yasir'; Muhammad Mansoor \\ Javed $^{3}$; Muhammad Ali Raza ${ }^{4}$; Muhammad Akram ${ }^{5}$
}

\begin{abstract}
Nitrogen $(\mathrm{N})$, being mobile in soil is exposed to various losses owing to unwise use of nitrogen fertilizer, and conventional soil and crop management practices which can be minimized by temporal nitrogen application and different tillage practices. This study was conducted to elucidate the effect of different tillage systems and nitrogen timings on growth, stay green and grain quality in maize. Three tillage systems viz. $\mathrm{T}_{1}$ : tillage with cultivator, $\mathrm{T}_{2}$ : mouldboard plough +2 -cultivations, $\mathrm{T} 3$ : chisel plough + 2-cultivations; and five nitrogen timings viz. $\mathrm{N}_{1}$ : whole at sowing, $\mathrm{N}_{2}: 1 / 2$ at sowing $+1 / 2$ at V5 (5-leaf stage), $\mathrm{N}_{3}: 1 / 2$ at sowing $+1 / 2$ at tasseling, $\mathrm{N}_{4}: 1 / 2$ at $\mathrm{V} 5+1 / 2$ at tasseling, $\mathrm{N}_{5}: 1 / 3$ at sowing $+1 / 3$ at $\mathrm{V} 5+1 / 3$ at tasseling). Tillage systems and nitrogen application had significant effect on leaf area per plant, specific leaf area and leaf area ratio. Tillage systems had non-significant effect on stay green and grain quality parameters except for oil contents. However, nitrogen timings had significant effect on chlorophyll a, b and total contents as well as grain quality parameters. The higher $\mathrm{a}, \mathrm{b}$ and total chlorophyll contents were noted with three splits i.e. $1 / 3$ at sowing $+1 / 3$ at $V 5+1 / 3$ at tasseling compared with other treatments. The results suggest to grow maize by preparing the field through chisel plough and applying $\mathrm{N}$ in three splits to improve its growth, chlorophyll contents and grain quality.
\end{abstract}

Key words: Chlorophyll contents. Leaf area ratio. Specific leaf area. Grain quality. Nitrogen application timings. Tillage systems.

\section{Resumo}

Nitrogênio $(\mathrm{N})$, sendo móvel no solo, está exposto a várias perdas devido ao uso imprudente de fertilizantes nitrogenados e práticas convencionais de manejo do solo e das culturas, que podem ser minimizadas pela aplicação de nitrogênio temporal e diferentes práticas de preparo do solo. Este estudo foi realizado para elucidar o efeito de diferentes sistemas de preparo do solo e tempos de nitrogênio no crescimento, permanência e qualidade do grão verde no milho. Três sistemas de lavoura, viz. T1: preparo do solo com cultivador, T2: arado de aiveca + 2-cultivos, T3: escarificador + 2-cultivos; e cinco

${ }^{1}$ Assistant Professor, College of Agriculture, BZU Bahadur Sub Campus, Layyah, Pakistan. E-mail: wasayauaf@gmail.com

2 Associate Professor, Department of Agronomy, University of Agriculture Faisalabad, Pakistan. E-mail:drtahirfsd@hotmail.com

3 Assistant Professor, Department of Agronomy, University of Sargodha, Sargodha, Pakistan. E-mail: mmansoorjavaid@gmail.com

4 Ph.D. Scholar, College of Agronomy, Sichuan Agricultural University, Chengdu 611130, Sichuan, China. E-mail: razaali0784@ yahoo.com

5 Assistant Professor, Department of Environmental Sciences, COMSATS University, Islamabad, Vehari Campus 61100, Pakistan. E-mail: akramcp@gmail.com

* Author for correspondence 
temporizações de azoto, viz. N1: todo na sementeira, N2: $1 / 2$ na sementeira $+1 / 2$ na V5 (fase de 5 folhas), N3: $1 / 2$ na sementeira $+1 / 2$ no pendoamento, N4: $1 / 2$ na V5 $+1 / 2$ na pompa, N5: $1 / 3$ na sementeira $+1 / 3$ em V5 + 1/3 no pendoamento). Sistemas de preparo do solo e aplicação de nitrogênio tiveram efeito significativo na área foliar por planta, área foliar específica e área foliar. Os sistemas de preparo do solo não tiveram efeito significativo na manutenção dos parâmetros de qualidade verde e de grãos, exceto para os teores de óleo. Entretanto, os tempos de nitrogênio tiveram efeito significativo sobre os teores de clorofila a, b e total, bem como parâmetros de qualidade de grãos. Os maiores teores de clorofila a, b e total foram observados com três fendas, isto é, $1 / 3$ na semeadura $+1 / 3$ em V5 $+1 / 3$ no pendoamento comparado com outros tratamentos. Os resultados sugerem o cultivo do milho preparando o campo através do arado de cinzel e aplicando o $\mathrm{N}$ em três fendas para melhorar o seu crescimento, o teor de clorofila e a qualidade do grão.

Palavras-chave: Teor de clorofila. Razão Área foliar. Área foliar específica. Qualidade de grãos. Intervalos de aplicação de nitrogênio. Sistemas de manejo.

\section{Introduction}

Tillage is one of the important agriculture practices because of its impact on crop growth, and soil health (SHARMA et al., 2011), which on one hand, alter crop yield (LIU; WIATRAK, 2012), including soil physical (D'HAENE et al., 2008), chemical (VILLAMIL; NAFZIGER, 2015) and biological properties (LUPWAYI et al., 2012). Due to soil compaction, water and nutrients supply to plants is restricted which leads towards reduction in crop growth and yield (HAMZA; ANDERSON, 2005). Lower bulk density due to subsoil compaction causes reductions in crop roots due to resistance to penetration (COELHO et al., 2000; YUSUF, 2006; WANG et al., 2009; JABRO et al., 2010) and soil cone index (WANG et al., 2009), hence resulting in poor crop yield. The existence of plough pan prevents penetration of rain water into deep soil layer and affect crop yield (MAO, 2009). However, it has been well documented that mechanical subsoiling efficiently reduced the soil strength thereby increasing root penetration (OLESEN; MUNKHOLM, 2007). Subsoiling improves soil aeration, increase the availability of nitrogen $(\mathrm{N})$ through organic nitrogen mineralization, and thus modifies the soil environment which is favorable for crop growth (HALVORSON et al., 2001; DINNES et al., 2002) and also increase root density as well as its distribution (MOSADDEGHI et al., 2009; SUN et al., 2017). This increase in root distribution helps to delay plant senescence (LIANG et al., 2010) and ultimately improves grain yield (HOU et al., 2013).

Nitrogen is highly susceptible to several losses such as leaching, denitrification, volatilization and immobilization which influence the $\mathrm{N}$ dynamics and makes $\mathrm{N}$ application timing a best tool to balance $\mathrm{N}$ demand for optimum plant growth and to reduce its losses in various forms (DINNES et al., 2002). Thus, practicing best $\mathrm{N}$ management can boost up $\mathrm{N}$ use efficiency (NUE) and crop yield (MA et al., 2012; MA; BISWAS, 2015). For improving NUE, $\mathrm{N}$ application timing is one of the important components, as per-plant application undergoes leaching losses. Split application of N reduces losses (MITCHELL et al., 2000) and results in higher maize yield (BAKHSH et al., 2002; JAMIL et al., 2015; WASAYA et al., 2017a) through improving grain components (WASAYA et al., 2017a). It has been noted that $\mathrm{N}$ application can improve photosynthetic rate and photosynthetic NUE (MA et al., 2010; MA; BISWAS, 2016). Increase in the photosynthesis rate with higher $\mathrm{N}$ supply in different maize hybrids has been reported (URIBELARREA et al., 2009). Increase in photosynthetic active leaf area due to higher chlorophyll contents results in higher grain yield (VANYINE et al., 2012; WASAYA et al., 2017a, 2018b) and biomass production (WASAYA et al., 2012). Although lot of work has been done on tillage and time of nitrogen application as an individual factor, however little information is 
available as combined effect of tillage and nitrogen timings in maize. Keeping this in view, the present study was carried out to check the combined effect of tillage and nitrogen application timings on growth, stay green and grain quality in maize.

\section{Materials and Methods}

\section{Experiment detail}

This two year field experiment was conducted during autumn season of 2008 and 2009 at the Agronomic Research Area, University of Agriculture, Faisalabad, Pakistan in order to assess the effect of tillage systems and nitrogen timings on growth dynamics, chlorophyll contents, dry matter production and grain quality of maize. The soil of experimental site is sandy clay loam with organic matter $(0.72 \%)$ and total $\mathrm{N}$ contents $(0.04 \%)$. The weather data is given in our paper published as Wasaya et al. (2018a).

Maize crop was sown under three different tillage systems viz. conventional tillage; tillage with moldboard plough; and tillage with chisel plough up to $40 \mathrm{~cm}$ depth followed by 2-cultivations with cultivator and one planking with five $\mathrm{N}$ application timings viz. whole at planting; $1 / 2$ at planting $+1 / 2$ at 5-leaf stage $\left(\mathrm{V}_{5}\right)(30 \mathrm{DAS}), 1 / 2$ at planting $+1 / 2$ at tasseling (VT) (50 DAS), $1 / 2$ at $\mathrm{V}_{5}+1 / 2$ at VT and $\mathrm{N}_{5}$ : $1 / 3$ at planting $+1 / 3$ at $\mathrm{V}_{5}+1 /{ }_{3}$ at VT. The treatments were applied in a split plot design by assigning tillage application and $\mathrm{N}$ timings in main and sub plots, respectively with net plot size of $4.5 \mathrm{~m} \times 10$ $\mathrm{m}$ having 3 replications.

\section{Crop husbandry}

Before maize planting to ensure homogenous moisture level, experimental area was irrigated at a depth of $10 \mathrm{~cm}$. Field was prepared according to treatments needs and maize hybrid pioneer-31R88 was sown on August 07, 2008 and August 01, 2009. The crop was planted with the help of dibbler by using $25 \mathrm{~kg} \mathrm{ha}^{-1}$ seed rate, maintaining line spacing of $0.75 \mathrm{~m}$ and a plant spacing of $0.2 \mathrm{~m}$. Initially two seeds were manually planted per hill and then one plant per hill was retained after thinning at 3-leaf stage. Nitrogen $(\mathrm{N})$ was applied @150 kg ha $^{-1}$ while phosphorous $(\mathrm{P})$ and potassium $(\mathrm{K})$ both were applied @100 kg ha-1 each. Total P and K were added to soil at the sowing time while $\mathrm{N}$ was applied according to the treatments. Single super phosphate (SSP), sulphate of potash (SOP) and urea were used as source of $\mathrm{P}, \mathrm{K}$ and N. Five irrigations were applied as and when needed by crop.

\section{Observations recorded}

\section{Growth parameters}

At maturity, 10 plants were cut from each plot, dried for 8 days under sun. After drying, plants were weighed to calculate dry matter yield ( $\left.\mathrm{g} \mathrm{plant}^{-1}\right)$.

For measurement of leaf area per plant, five (5) plants were harvested from each plot with 15 days interval starting from 40 days after planting up to 100 DAP. Leaves were separated from stem then leaf area was calculated using leaf area meter. On the basis of leaf area, specific leaf area and leaf area ratio were calculated using formulae as given below.

$$
\begin{aligned}
\text { Specific leaf area } & =\frac{\text { leaf area per plant }}{\text { Leaf weight per plant }}(\mathrm{cm} 2 g-1) \\
\text { Leaf area ratio } & =\frac{\text { Leaf area per palnt }}{\text { weight per plant }}(\mathrm{cm} 2 g-1)
\end{aligned}
$$




\section{Chlorophyll contents $(\mu M)$}

For chlorophyll (a, b and total) content determination, five flag leaves were selected randomly from each experimental plot and were separated from the plant stem. The leaf samples were taken at two reproductive stages viz. at blister (R2) and dough (R4) stages. These leaf samples were cut into small pieces and then frozen for overnight. About $2 \mathrm{~g}$ frozen leaves from each sample were ground with the help of mortar and pestle in $80 \%$ acetone solution. The grinded samples were then kept in dark for few hours to allow the leaf tissues to be homogenized thoroughly. The extracts of each sample were centrifuged for 10 minutes at $6000 \mathrm{rpm}$ and absorbance of the supernatant was observed using a UV spectrophotometer (Unicam 8620 ) at 647 and $664 \mathrm{~nm}$, and the chlorophyll a, b and total chlorophyll contents were calculated using the formulae as reported by COOMBS et al. (1987).

\section{Grain quality}

For estimation of protein contents, the grain samples were oven dried at $70{ }^{\circ} \mathrm{C}$ for $24 \mathrm{~h}$. After drying, the samples were grinded with mechanical grinding machine and $\mathrm{N}$ content in maize grain was estimated using micro-Kjeldahl method (AOAC, 1990) and protein contents were calculated using following formula

\section{Protein content $(\%)=N$ concentarion $\times 6.25$}

Oil contents in maize grain were estimated by Soxhlet method as proposed by Low (1990) and starch contents were estimated by Gluco-amylase method (AOAC, 1990).

\section{Statistical analysis}

Data collected were interpreted using software statistix 8.1. To compare the means of different treatments, analysis of variance technique and LSD test was used at 5\% probability level (STEEL et al., 1997).

\section{Results}

Tillage with chisel plough improved the leaf area per plant (LAPP) while tillage with MBP caused decrease in leaf area per plant during both years of study (Figure 1), but this increase was higher during first year of study compared with second year (Figure 1). Among different $\mathrm{N}$ application timings, $\mathrm{N}_{5}$ (i.e. $\mathrm{N}$ in three splits) produced higher leaf area per plant compared with other treatments with minimum leaf area per plant in $\mathrm{N}_{4}$ (Figure 2). However, specific leaf area showed reverse results than leaf area per plant and higher specific leaf area was noted in MBP compared with other tillage systems with minimum value found in $\mathrm{CP}$ during both study years (Figure 2). Maize grown with nitrogen application at sowing time $\left(\mathrm{N}_{1}\right)$ produced higher specific leaf area compared with other treatments (Figure 2). Specific leaf area was reduced with the passage of time as the crop grow older it showed reduction with higher value at 40 days after sowing (DAS), while minimum value was specific leaf area was noted at 100 DAS during both years (Figure 2). Similarly, higher leaf area ratio (LAR) was noted in conventional tillage (CT) compared with other treatments during both study years (Figure 3). Nitrogen application timings also had significant effect on LAR and higher LAR was observed in $\mathrm{N}_{5}$ while lower was noted in $\mathrm{N}_{1}$ during both years (Figure 3). 
Figure 1. Tillage systems and nitrogen timings effect on leaf area per plant in maize.

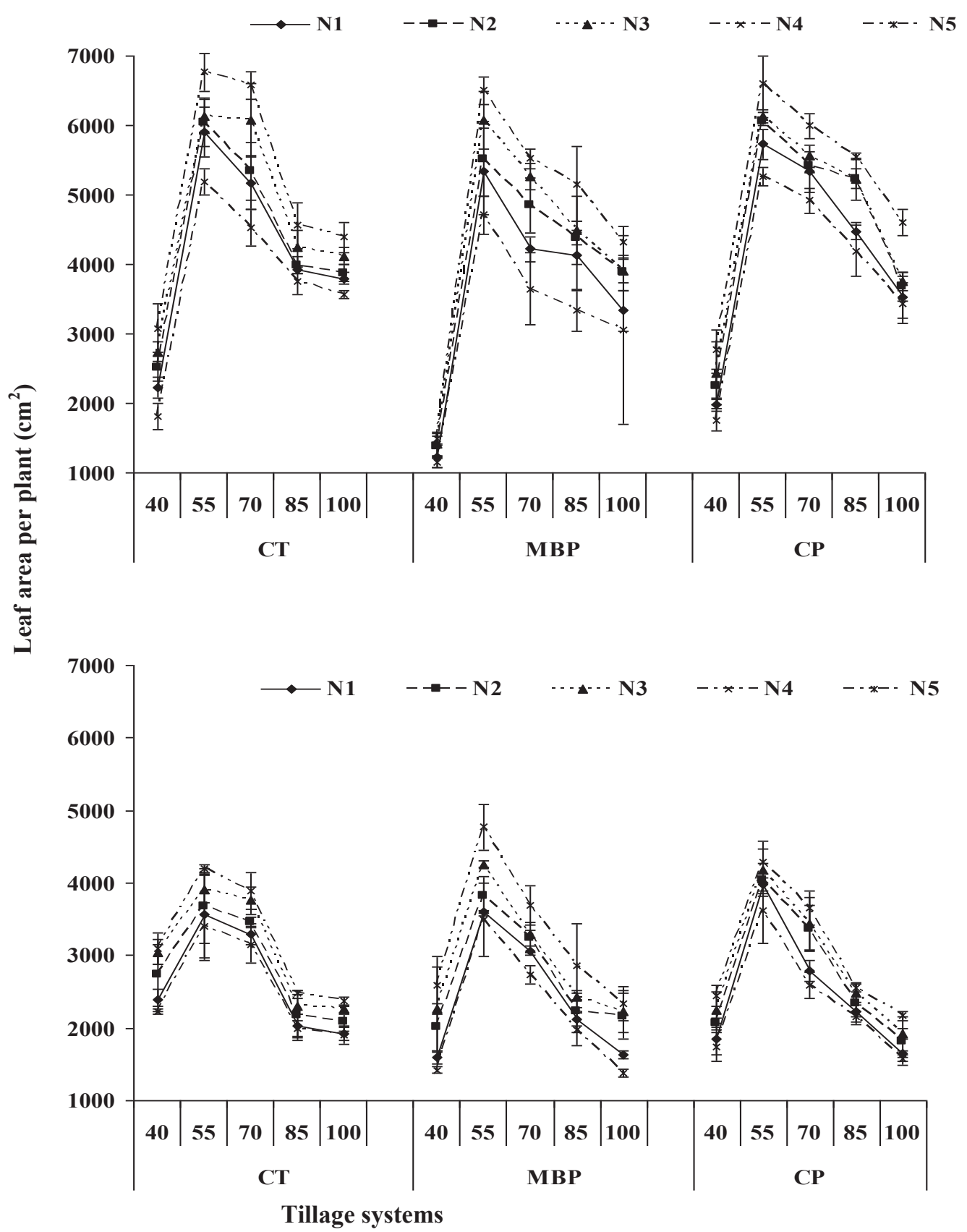

Here $\mathrm{CT}=$ Conventional tillage; $\mathrm{MBP}=$ Mouldboard plough; $\mathrm{CP}=$ Chisel plough; $\mathrm{N}_{1}=$ Whole $\mathrm{N}$ application at sowing, $\mathrm{N}_{2}=1 / 2$ at sowing $+1 / 2$ at $V 5$ (5-leaf stage), $N_{3}=1 / 2$ at sowing $+1 / 2$ at tasseling, $N_{4}=1 / 2$ at $V 5+1 / 2$ at tasseling, $N_{5}=1 / 3$ at sowing $+1 / 3$ at $V 5+$ $1 / 3$ at tasseling. 
Figure 2. Tillage systems and nitrogen timings effect on specific leaf area in maize.

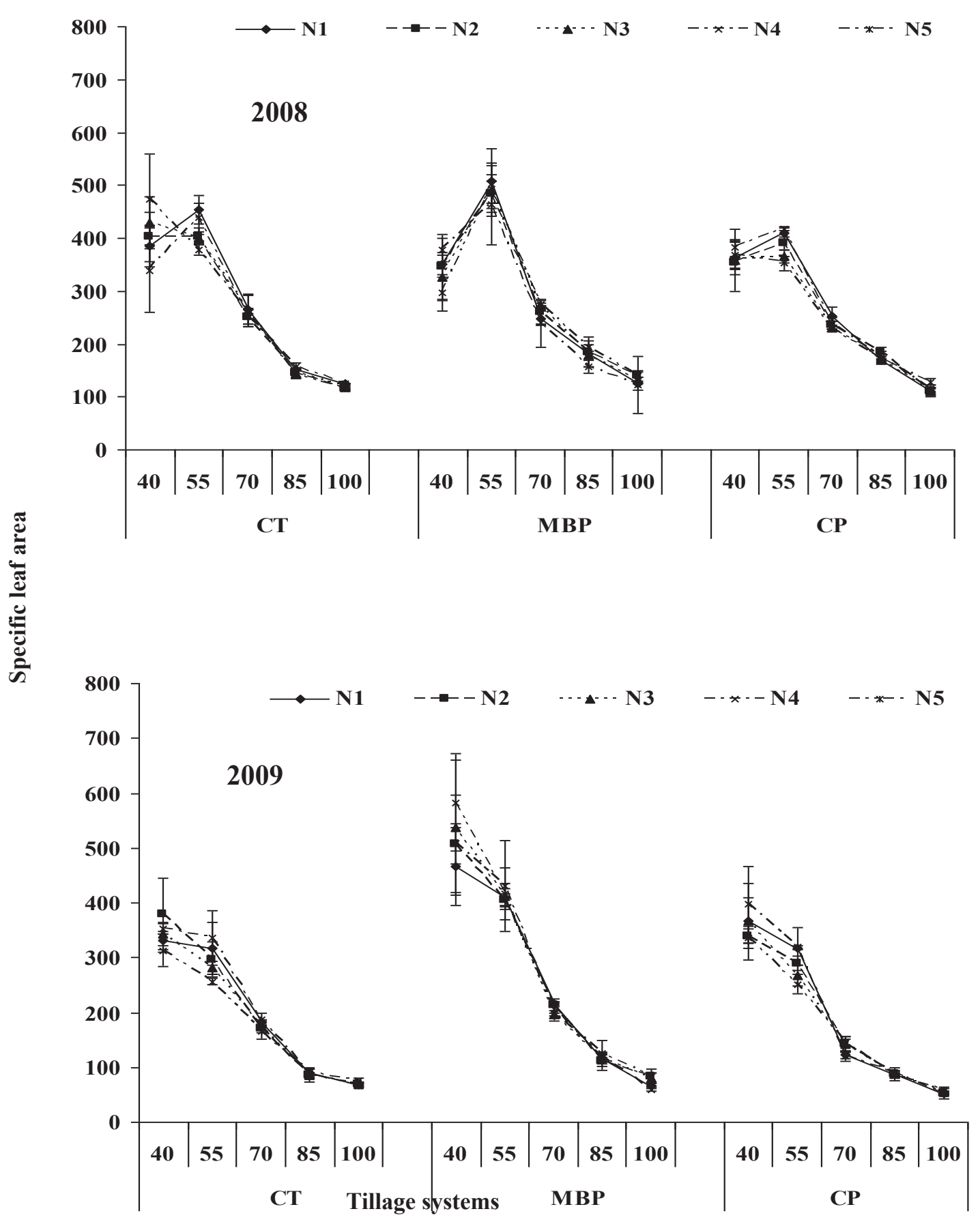

Here $\mathrm{CT}=$ Conventional tillage; $\mathrm{MBP}=$ Mouldboard plough; $\mathrm{CP}=$ Chisel plough; $\mathrm{N}_{1}=$ Whole $\mathrm{N}$ application at sowing, $\mathrm{N}_{2}=1 / 2$ at sowing $+1 / 2$ at V5 (5-leaf stage), $N_{3}=1 / 2$ at sowing $+1 / 2$ at tasseling, $N_{4}=1 / 2$ at $V 5+1 / 2$ at tasseling, $N_{5}=1 / 3$ at sowing $+1 / 3$ at V5 + $1 / 3$ at tasseling. 
Figure 3. Tillage systems and nitrogen timings effect on leaf area ration in maize.

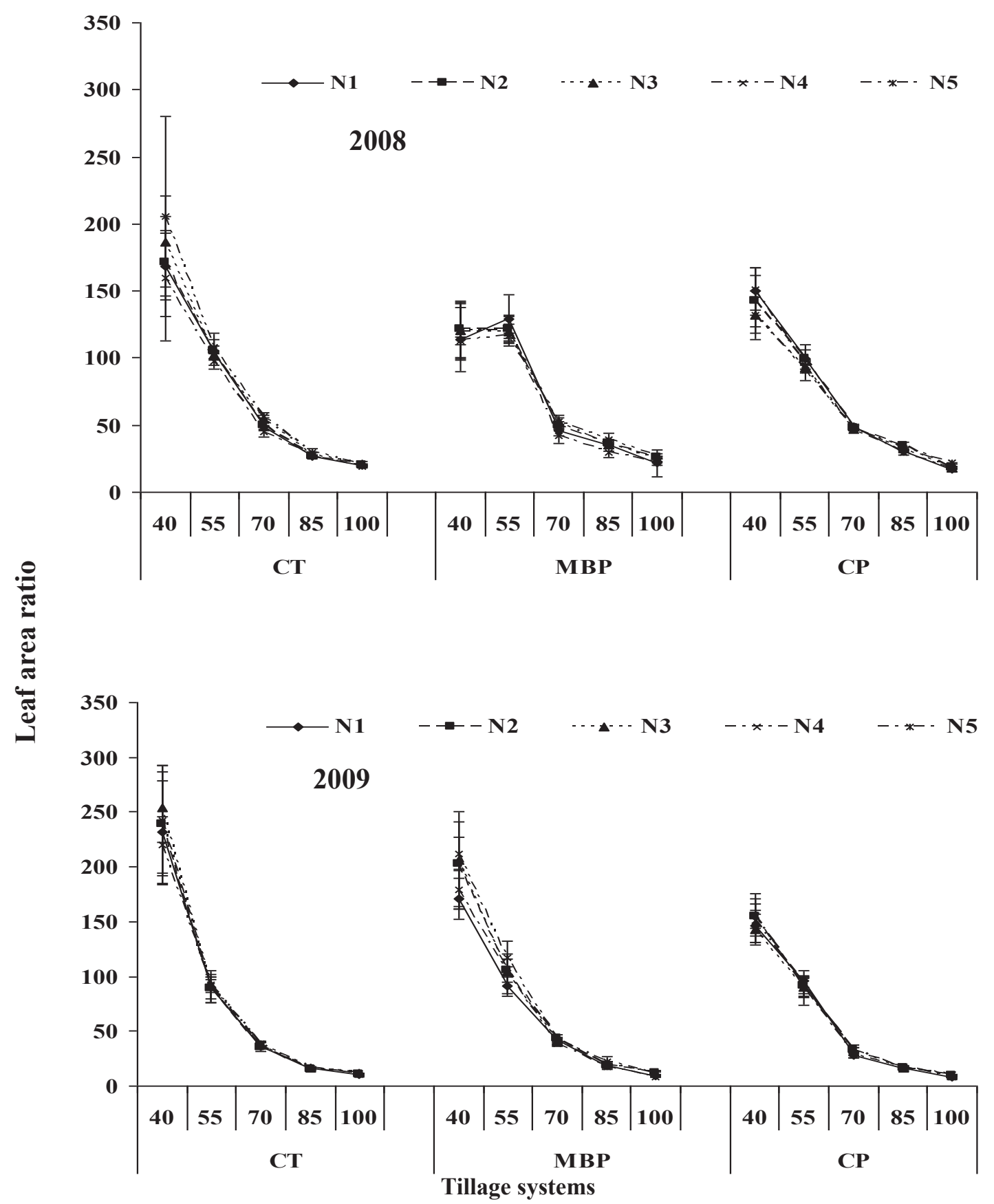

Here $\mathrm{CT}=$ Conventional tillage; $\mathrm{MBP}=$ Mouldboard plough; $\mathrm{CP}=$ Chisel plough; $\mathrm{N}_{1}=$ Whole $\mathrm{N}$ application at sowing, $\mathrm{N}_{2}=1 / 2$ at sowing $+1 / 2$ at V5 (5-leaf stage), $\mathrm{N}_{3}=1 / 2$ at sowing $+1 / 2$ at tasseling, $\mathrm{N}_{4}=1 / 2$ at V5 $+1 / 2$ at tasseling, $\mathrm{N}_{5}=1 / 3$ at sowing $+1 / 3$ at V5 + $1 / 3$ at tasseling.

Different tillage systems had non-significant effect on $\mathrm{a}, \mathrm{b}$ and total chlorophyll contents at both blister (R2) as well dough (R4) stages. While nitrogen application timings had significant effect on chlorophyll contents and $\mathrm{N}_{5}$ showed higher $\mathrm{a}, \mathrm{b}$ and total chlorophyll contents compared with other treatments with minimum values for $\mathrm{N}_{4}$ (Tables 1 , 2). Various tillage systems had non-significant effect 
on protein and starch contents while significant effect on oil contents (Table 3) during both years, while $\mathrm{N}$ application timing had significant effect on protein, oil and starch contents during both years (Table 3). However, higher protein contents were observed with $\mathrm{N}_{5}$ compared with other treatments with minimum protein contents in $\mathrm{N}_{1}$ during both study years. Regarding oil contents, higher oil contents were found in $\mathrm{N}_{1}$ while lower with $\mathrm{N}_{5}$.
Similarly, higher starch contents were noted for $\mathrm{N}_{1}$ compared with other treatments during both study years (Table 3 ). The maximum oil contents were noted in plots where maize was grown by preparing the field with MBP and whole nitrogen was applied at sowing with minimum value in maize grown by ploughing the field with $\mathrm{CT}$ and applying $\mathrm{N}$ in two splits (i.e. $1 / 2$ at planting $+1 / 2$ at $\mathrm{V}_{5}$ ) during both study years (Table 4).

Table 1. Effect of different tillage systems and time of nitrogen application on chlorophyll contents at blister stage (R2-stage) in maize.

\begin{tabular}{ccccc}
\hline Treatments & & Chlorophyll a & Chlorophyll b & Total chlorophyll \\
\hline Tillage (T) & $\mathrm{CT}$ & 23.69 & 16.11 & 39.810 \\
& $\mathrm{MBP}$ & 23.11 & 15.72 & 38.84 \\
& $\mathrm{CP}$ & 23.58 & 16.39 & 39.97 \\
& $\mathrm{LSD}(0.05)$ & $\mathrm{NS}$ & $\mathrm{NS}$ & $\mathrm{NS}$ \\
\hline \multirow{3}{*}{ Nitrogen (N) } & & & & \\
& $\mathrm{N}_{1}$ & $21.97 \mathrm{c}$ & $14.40 \mathrm{~d}$ & $36.37 \mathrm{~d}$ \\
& $\mathrm{~N}_{2}$ & $23.03 \mathrm{c}$ & $16.30 \mathrm{c}$ & $39.33 \mathrm{c}$ \\
& $\mathrm{N}_{3}$ & $24.57 \mathrm{~b}$ & $18.05 \mathrm{~b}$ & $42.63 \mathrm{~b}$ \\
& $\mathrm{~N}_{4}$ & $20.64 \mathrm{~d}$ & $12.32 \mathrm{e}$ & $32.96 \mathrm{e}$ \\
& $\mathrm{N}_{5}$ & $27.10 \mathrm{a}$ & $19.30 \mathrm{a}$ & $46.41 \mathrm{a}$ \\
& $\mathrm{LSD}(0.05)$ & 1.14 & 1.18 & 1.669 \\
& $\mathrm{~T} \times \mathrm{N}$ & $\mathrm{NS}$ & $\mathrm{NS}$ & $\mathrm{NS}$ \\
\hline
\end{tabular}

Here $\mathrm{CT}=$ Conventional tillage; $\mathrm{MBP}=$ Mouldboard plough; $\mathrm{CP}=$ Chisel plough; $\mathrm{N}_{1}=$ Whole $\mathrm{N}$ application at sowing, $\mathrm{N}_{2}=1 / 2$ at sowing $+1 / 2$ at V5 (5-leaf stage), $\mathrm{N}_{3}=1 / 2$ at sowing $+1 / 2$ at tasseling, $\mathrm{N}_{4}=1 / 2$ at V5 $+1 / 2$ at tasseling, $\mathrm{N}_{5}=1 / 3$ at sowing $+1 / 3$ at V5 + $1 / 3$ at tasseling.

Table 2. Effect of different tillage systems and time of nitrogen application on chlorophyll contents at dough stage (R4-stage) in maize.

\begin{tabular}{ccccc}
\hline Treatments & & Chlorophyll a & Chlorophyll b & Total chlorophyll \\
\hline Tillage (T) & CT & 18.47 & 14.23 & 32.70 \\
& MBP & 18.24 & 13.878 & 32.11 \\
& CP & 19.23 & 13.66 & 32.89 \\
& LSD $(0.05)$ & NS & NS & NS \\
\hline \multirow{3}{*}{ Nitrogen (N) } & & & & \\
& $\mathrm{N}_{1}$ & $16.81 \mathrm{~d}$ & $12.39 \mathrm{bc}$ & $29.20 \mathrm{~d}$ \\
& $\mathrm{~N}_{2}$ & $18.64 \mathrm{c}$ & $13.79 \mathrm{~b}$ & $32.43 \mathrm{c}$ \\
& $\mathrm{N}_{3}$ & $20.15 \mathrm{~b}$ & $15.38 \mathrm{a}$ & $35.53 \mathrm{~b}$ \\
& $\mathrm{~N}_{4}$ & $15.73 \mathrm{~d}$ & $11.39 \mathrm{c}$ & $27.12 \mathrm{~d}$ \\
& $\mathrm{~N}_{5}$ & $21.91 \mathrm{a}$ & $16.66 \mathrm{a}$ & $38.57 \mathrm{a}$ \\
& $\mathrm{LSD}(0.05)$ & 1.378 & 1.472 & 2.24 \\
& $\mathrm{~T} \times \mathrm{N}$ & $\mathrm{NS}$ & $\mathrm{NS}$ & $\mathrm{NS}$ \\
\hline
\end{tabular}

Here $\mathrm{CT}=$ Conventional tillage; $\mathrm{MBP}=$ Mouldboard plough; $\mathrm{CP}=$ Chisel plough; $\mathrm{N}_{1}=$ Whole $\mathrm{N}$ application at sowing, $\mathrm{N}_{2}=1 / 2$ at sowing $+1 / 2$ at V5 (5-leaf stage), $\mathrm{N}_{3}=1 / 2$ at sowing $+1 / 2$ at tasseling, $\mathrm{N}_{4}=1 / 2$ at V $5+1 / 2$ at tasseling, $\mathrm{N}_{5}=1 / 3$ at sowing $+1 / 3$ at V5 + $1 / 3$ at tasseling. 
Table 3. Effect of different tillage systems and time of nitrogen application on grain protein, oil and starch contents in maize.

\begin{tabular}{|c|c|c|c|c|c|}
\hline Year & & & Protein content $(\%)$ & Oil content $(\%)$ & Starch content $(\%)$ \\
\hline \multirow[t]{11}{*}{2008} & Tillage (T) & $\mathrm{CT}$ & 8.13 & $3.24 \mathrm{~b}$ & 70.94 \\
\hline & & MBP & 8.09 & $3.66 \mathrm{a}$ & 71.33 \\
\hline & & $\mathrm{CP}$ & 8.13 & $3.39 \mathrm{~b}$ & 71.20 \\
\hline & & $\operatorname{LSD}(0.05)$ & NS & 0.15 & NS \\
\hline & Nitrogen $(\mathrm{N})$ & $\mathrm{N}_{1}$ & $8.03 \mathrm{~d}$ & $3.77 \mathrm{a}$ & $72.30 \mathrm{a}$ \\
\hline & & $\mathrm{N}_{2}$ & $8.06 \mathrm{~cd}$ & $3.41 \mathrm{~b}$ & $70.07 \mathrm{c}$ \\
\hline & & $\mathrm{N}_{3}$ & $8.15 \mathrm{~b}$ & $3.31 \mathrm{c}$ & $71.82 \mathrm{ab}$ \\
\hline & & $\mathrm{N}_{4}$ & $8.10 \mathrm{bc}$ & $3.42 \mathrm{~b}$ & $70.42 \mathrm{bc}$ \\
\hline & & $\mathrm{N}_{5}$ & $8.23 \mathrm{a}$ & $3.23 \mathrm{~d}$ & $71.16 \mathrm{abc}$ \\
\hline & & $\operatorname{LSD}(0.05)$ & 0.06 & 0.08 & 1.51 \\
\hline & & $\mathrm{T} \times \mathrm{N}$ & NS & $*$ & NS \\
\hline \multirow[t]{11}{*}{2009} & Tillage (T) & $\mathrm{CT}$ & 8.07 & $3.29 \mathrm{~b}$ & 71.21 \\
\hline & & MBP & 8.04 & $3.70 \mathrm{a}$ & 71.73 \\
\hline & & $\mathrm{CP}$ & 8.05 & $3.42 \mathrm{~b}$ & 71.40 \\
\hline & & LSD (0.05) & NS & 0.17 & $\mathrm{NS}$ \\
\hline & Nitrogen $(\mathrm{N})$ & $\mathrm{N}_{1}$ & $7.97 \mathrm{c}$ & $3.79 \mathrm{a}$ & $72.74 \mathrm{a}$ \\
\hline & & $\mathrm{N}_{2}$ & $8.00 \mathrm{c}$ & $3.45 \mathrm{~b}$ & $70.39 \mathrm{~b}$ \\
\hline & & $\mathrm{N}_{3}$ & $8.09 \mathrm{ab}$ & $3.34 \mathrm{c}$ & $72.11 \mathrm{a}$ \\
\hline & & $\mathrm{N}_{4}^{3}$ & $8.03 \mathrm{bc}$ & $3.49 \mathrm{~b}$ & $70.59 \mathrm{~b}$ \\
\hline & & $\mathrm{N}_{5}^{4}$ & $8.16 \mathrm{a}$ & $3.28 \mathrm{c}$ & $71.39 \mathrm{ab}$ \\
\hline & & $\operatorname{LSD}(0.05)$ & 0.08 & 0.10 & 1.44 \\
\hline & & $\mathrm{T} \times \mathrm{N}$ & NS & $*$ & NS \\
\hline
\end{tabular}

Here $\mathrm{CT}=$ Conventional tillage; $\mathrm{MBP}=$ Mouldboard plough; $\mathrm{CP}=$ Chisel plough; $\mathrm{N}_{1}=$ Whole $\mathrm{N}$ application at sowing, $\mathrm{N}_{2}=1 / 2$ at sowing $+1 / 2$ at V5 (5-leaf stage), $\mathrm{N}_{3}=1 / 2$ at sowing $+1 / 2$ at tasseling, $\mathrm{N}_{4}=1 / 2$ at V5 $+1 / 2$ at tasseling, $\mathrm{N}_{5}=1 / 3$ at sowing $+1 / 3$ at V5 + $1 / 3$ at tasseling.

Table 4. Interactive effect of different tillage systems and time of nitrogen application on grain oil contents.

\begin{tabular}{cccc}
\hline Tillage & Nitrogen & Oil content (\%) (2008) & Oil content (\%) (2009) \\
\hline CT & $\mathrm{N}_{1}$ & $3.45 \mathrm{bc}$ & $3.48 \mathrm{bc}$ \\
& $\mathrm{N}_{2}$ & $2.98 \mathrm{~g}$ & $3.06 \mathrm{~g}$ \\
& $\mathrm{~N}_{3}$ & $3.19 \mathrm{ef}$ & $3.26 \mathrm{def}$ \\
& $\mathrm{N}_{4}$ & $3.06 \mathrm{fg}$ & $3.13 \mathrm{efg}$ \\
& $\mathrm{N}_{5}$ & $3.51 \mathrm{~b}$ & $3.51 \mathrm{~b}$ \\
& $\mathrm{~N}_{1}$ & $3.95 \mathrm{a}$ & $3.98 \mathrm{a}$ \\
& $\mathrm{N}_{2}$ & $3.91 \mathrm{a}$ & $3.96 \mathrm{a}$ \\
& $\mathrm{N}_{3}$ & $3.51 \mathrm{~b}$ & $4.00 \mathrm{bc}$ \\
$\mathrm{NP}$ & $\mathrm{N}_{4}$ & $3.92 \mathrm{a}$ & $3.10 \mathrm{fg}$ \\
& $\mathrm{N}_{5}$ & $3.00 \mathrm{~g}$ & $3.91 \mathrm{a}$
\end{tabular}




\begin{tabular}{ccc}
\hline $\mathrm{N}_{2}$ & $3.35 \mathrm{~cd}$ & $3.32 \mathrm{~cd}$ \\
$\mathrm{~N}_{3}$ & $3.22 \mathrm{de}$ & $3.28 \mathrm{de}$ \\
$\mathrm{N}_{4}$ & $3.27 \mathrm{de}$ & $3.35 \mathrm{bcd}$ \\
$\mathrm{N}_{5}$ & $3.17 \mathrm{ef}$ & $3.22 \mathrm{defg}$ \\
\hline LSD $(0.05)$ & 0.13 & 0.17 \\
\hline
\end{tabular}

Here $\mathrm{CT}=$ Conventional tillage; $\mathrm{MBP}=$ Mouldboard plough; $\mathrm{CP}=$ Chisel plough; $\mathrm{N}_{1}=$ Whole $\mathrm{N}$ application at sowing, $\mathrm{N}_{2}=1 / 2$ at sowing $+1 / 2$ at V5 (5-leaf stage), $\mathrm{N}_{3}=1 / 2$ at sowing $+1 / 2$ at tasseling, $\mathrm{N}_{4}=1 / 2$ at V $5+1 / 2$ at tasseling, $\mathrm{N}_{5}=1 / 3$ at sowing $+1 / 3$ at V5 + $1 / 3$ at tasseling.

\section{Discussion}

Tillage systems had significant effect on soil properties and root distribution (HAMZA; ANDERSON, 2005; HOU et al., 2012) and had direct impact on leaf area per plant and specific leaf area (Fig 1-3). In present study, increase in leaf area per plant in chisel ploughed plots might be due to higher root proliferation (SUN et al., 2017), which helped to delay leaf senescence (LIANG et al., 2010) and ultimately improved leaf area per plant (Figure 1) (SUN et al., 2017). However, less leaf area per plant under mould board ploughed plots was due to higher bulk density and lower porosity of soil which restricted roots to upper soil and reduced uptake of nutrients and water (BENGOUGH et al., 2011; EKELOF et al., 2015). Similarly, N application in three splits produced higher leaf area per plant compared with other treatments which might be due to availability of nitrogen at all plant growth stages which ultimately improved leaf area per plant. This increase in leaf area per plant resulted in increased LAR (Figure 3) under split application (AMANULLAH et al., 2007). This increase in leaf area per plant led to increase in leaf is index (LAI) as well as grain and biomass production (WASAYA et al., 2017a,b).

Different tillage systems had non-significant effect on chlorophyll $\mathrm{a}, \mathrm{b}$ and total chlorophyll contents at both blister (R2) as well dough (R4) stages (Tables 1, 2). The same non-significant effect of tillage systems on chlorophyll SPAD value was also reported by Liu and Wiatrak (2012) in maize crop. However, nitrogen application in splits significantly improved stay green which was visible through improved values of chlorophyll contents (Tables $1,2)$. This increase in stay green might be due to $\mathrm{N}$ availability at all growth stages which improved chlorophyll contents as nitrogen is important for chlorophyll synthesis and photosynthetic activity (TURNBULL et al., 2007).

Grain quality is an important parameter with reference to product quality as well as nutrient composition. The results of current study indicated that different tillage systems had no significant effect on grain protein and starch contents while significant effect on oil contents. Grain oil contents were significantly influenced by tillage operations and highest oil contents were produced in grain obtained from plots treated with board plough followed by chisel plough and conventional tillage. Cociu and Alionte (2011) stated that grain contents in a zero tilled sown crop were significantly higher than those were grown in moldboard and disc plough tillage systems. Similarly decrease in oil contents under chisel ploughed plots might be due more grain protein contents as these are contrary to each other as increase of one component lead to decrease in other nutrient. This might be due more uptake of nitrogen from deeper soil layer which is an important constituent of protein and hence led to decrease in oil contents (VITA et al., 2007; BOOMSMA et al., 2009; ANDRIJA et al., 2009).

In present study, timing of nitrogen application had significant $(\mathrm{p} \leq 0.05)$ effect on grain protein content. It has been documented that nitrogen fertilization at reproductive stage increases $\mathrm{N}$ 
contents in grains (SILVA et al., 2005) and results in increased grain protein contents (AMANULLAH; SHAH, 2010). Similarly, decreased protein contents in $\mathrm{N}_{1}$ (whole $\mathrm{N}$ application at sowing) might be due to higher losses of nitrogen at early growth stages (GALLAIS; BERTIN, 2008). Reduced concentration of grain oil in $\mathrm{N}_{5}(1 / 3$ at sowing $+1 / 3$ at V $5+1 / 3$ at tasseling) might be due to supply of $\mathrm{N}$ at all growth stages which resulted in reduction of oil contents. These results might be due to higher negative relation between $\mathrm{N}$ and oil content. However, grain oil contents were significantly higher in plants having sole application of $\mathrm{N}$ compared with those fertilized with split doses of N. Increase in starch contents under splits application might be due to availability of $\mathrm{N}$ for whole crop season which led to healthy crop and ultimately resulted in higher grain starch contents (Table 3) (MUTHUKUMAR et al., 2005).

\section{Conclusion}

Tillage systems and nitrogen timings had significant effect on leaf area per plant, specific leaf area and leaf area ratio. Tillage systems had nonsignificant while nitrogen timings had significant effect on stay green and grain quality parameters. The higher $\mathrm{a}, \mathrm{b}$ and total chlorophyll contents were noted in treatment where $\mathrm{N}$ was applied in 3-splits compared with all other treatments. Similarly, higher protein contents were noted with $\mathrm{N}_{5}$ compared with other treatments while, higher oil and starch contents were noted with $\mathrm{N}_{1}$. Chiseling the subsoil is a useful tool for improving growth of maize crop. Similarly, N should be applied in three splits to improve its growth, stay green as well as grain quality in terms of proteins contents which is major constituent of maize grain.

\section{References}

AMANULLAH.; HASSAN, M. J.; NAWAB, K.; ALI, A. Response of specific leaf area (SLA), leaf area index (LAI) and leaf area ratio (LAR) of maize (Zea mays L.) to plant density, rate and timing of nitrogen application. World Applied Sciences Journal, v. 2, n. 3, p. 235-243, 2007.

AMANULLAH; SHAH, P. Timing and rate of nitrogen application influence grain quality and yield in maize planted at high and low densities. Journal of the Science of Food and Agriculture, v. 90, n. 1, p. 21-29, 2010. DOI: 10.1002/jsfa.3769

ANDRIJA, S.; KVATERNJAK, I.; KISIC, I.; BIRKAS, M.; MARENCIC, D.; OREHOVACKI, V. Influence of tillage on soil properties, yields and protein content in grain of maize and soyabean. Journal of Environmental Protection and Ecology, v. 10, n. 4, p.1013-1031, 2009.

BAKHSH, A.; KANWAR, R. S.; BAILEY, T. B.; CAMBARDELLA, C. A.; KARLEN, D. L.; COLVIN, T. S. Cropping system effects on NO3- N loss with subsurface drainage water. Transactions of American Society of Agricultural Engineers, v. 45, n. 6, p. 17891797, 2002. DOI: $10.13031 / 2013.11430$

BENGOUGH, A. G.; MCKENZIE, B. M.; HALLETT, P. D.; VALENTINE, T. A. Root elongation water stress, and mechanical impedance: a review of limiting stresses and beneficial root tip traits. Journal of Experimental Botany, v. 62 , n. 1, p. 59-68, 2011. DOI: $10.1093 / \mathrm{jxb} / \mathrm{erq} 350$.

BOOMSMA, C. R.; SANTINI, J. B.; TOLLENAAR, M.; VYN, T. J. Maize morphophysiological response to intense crowing and low nitrogen availability: an analysis and review. Agronomy Journal, Madison, v. 101, n. 6, p. 1426-1452, 2009. DOI: 10.2134/agronj2009.0082.

COCIU, A. I.; ALIONTE, E. Yield and some quality traits of winter wheat, maize and soybean, grown in different tillage and deep loosening systems aimed to soil conservation. Romanian Agricultural Research, v. 28, n. 1, p. 109-120, 2011.

COELhO, M. B.; MATEOS, L.; VILLALOBOS, F. J. Influence of a compacted loam subsoil layer on growth and yield of irrigated cotton in Southern Spain. Soil and Tillage Research, Amsterdam, v. 57, n. 3, p. 129-142, 2000. DOI: 10.1016/S0167-1987(00)00153-7

COOMBS, J.; HIND, G.; LEEGOOD, R. C.; TIESZEN, L. L.; VONSHAK, A. Analytical techniques. In: COOMBS, J.; HALL, D. O.; LONG, S. P.; SCURLOCK, J. M. O. (Ed.). Techniques in bio-productivity and photosynthesis. New York: Pergamon Press, 1987. p. 219-227.

D'HAENE, K.; VERMANG, J.; CORNELIS, M. W.; LEROY, B. L. M.; SCHIETTECATTE, W.; NEVE, D. S.; GABRIELS, D.; HOFMAN, G. Reduced tillage effects on physical properties of silt loam soils growing root crops. Soil and Tillage Research, Amsterdam, v. 99, n. 2, p. 279-290, 2008. DOI: 10.1016/j.still.2008.03.003 
DINNES, D. L.; KARLEN, D. L.; JAYBES, D. B.; KASPAR, T. C.; HATFIELD, J. L.; COLVIN, T. S.; CAMBARDELLA, C. A. Nitrogen management strategies to reduce nitrate leaching in tile-drained midwestern soils. Agronomy Journal, Madison, v. 94, n. 1, p. 153-171, 2002. DOI: 10.2134/agronj2002.0153

EKELOF, J.; GUAMAN, V.; JENSEN, E. S.; PERSSON, P. Inter-row subsoiling and irrigation increase starch potato yield, phosphorus use efficiency and quality parameters. Potato Research, v. 58, n. 1, p. 15-27, 2015. DOI: $10.1007 / \mathrm{s} 11540-014-9261-5$

GALLAIS, A.; COQUE, M.; BERTIN, P. Response to selection of a maize population for adaptation to high or low nitrogen fertilization. Maydica, v. 53, n. 1, p. 21-28, 2008.

HALVORSON, A. D.; BRIAN, J. W.; ALFRED, L. B. Tillage, nitrogen, and cropping system effects on soil carbon sequestration. Soil Science Society of America Journal, v. 66, n. 1, p. 906-912, 2002. DOI:

HAMZA, M. A.; ANDERSON, W. K. Soil compaction in cropping systems. A review of the nature causes and possible solutions. Soil and Tillage Research, Amsterdam, v. 82, n. 2, p. 121-145, 2005. DOI: 10.1016/j. still.2004.08.009

HOU, H. P.; DING, Z. S.; MA, W.; LI, C. F.; ZHAO, M. Yield performance characteristics and regulation effects of plant density and sub-soiling tillage system for high yield population of summer maize. Acta Agronomica Sinica, v. 39, n. 6, p. 1069-1077, 2013. DOI:10.3724/ SP.J.1006.2013.01069

HOU, X. Q.; LI, R.; JIA, Z. K.; HAN, Q. F.; WANG, W.; YANG, B. P. Effects of rotational tillage practices on soil properties, winter wheat yields and water-use efficiency in semi-arid areas of north-west China. Field Crops Research, v. 129, n. 4, p. 7-13, 2012. DOI: 10.1016/j. fcr.2011.12.021

JABRO, J. D.; STEVENS, W. B.; IVERSEN, W. M.; EVANS, R. G. Tillage depth effects on soil physical properties, sugarbeet yield and sugarbeet quality. Communications in Soil Science and Plant Analysis, v. 41, n. 7, p. 908-916, 2010. DOI: 10.1080/00103621003594677

JAMIL, M.; SAJAD, A.; AHMAD, M.; AKHTAR, M. F.; ABBASI, G. H.; ARSHAD, M. Growth, yield and quality of maize (Zea mays L.) fodder as affected by nitrogenzinc interaction in arid climate. Pakistan Journal of Agricultural Sciences, v. 52, n. 3, p. 637-643, 2015.

LIANG, J. F.; QI, Q. Z.; JIAX. H., GONG, S. J.; HUANG, Y. F. Effects of different tillage managements on soil properties and corn growth. Ecology and Environmental
Sciences, v. 19, n. 4, p. 945-950, 2010.

LIU, K.; WIATRAK, P. Corn production response to tillage and nitrogen application in dryland environment. Soil and Tillage Research, Amsterdam, v. 124, n. 8, p. 138-143, 2012. DOI: 10.1016/j.still.2012.05.017

LOW, N. H. Food analysis, 417/717. Laboratory manual deptt. of Applied Microbiology and Food Science: Uini. Saskatchewan, 1990.

LUPWAYI, N. Z.; LNAFOND, G. P.; ZIADI, N.; GRANT, A. G. Soil microbial response to nitrogen fertilizer and tillage in barley and corn. Soil and Tillage Research, Amsterdam, v. 118, n. 1, p. 139-146, 2012. DOI:10.1016/j.still.2011.11.006

MA, B. L.; BISWAS, D. K. Field-level comparison of nitrogen rates and application methods on maize yield, grain quality and nitrogen use efficiency in a humid environment. Journal of Plant Nutrition, v. 39, n. 5, p. 727-741, 2016. DOI: 10.1080/01904167.2015.1106556

MA, B. L.; BISWAS, D. K. Precision N management for sustainable corn production. In: LICHTFOUSE, E.; GOYAL, A. (Ed.). Sustainable agriculture reviews. New York: Springer Publishing, 2015. Chapter 2, v. 6, p. X-x.

MA, B. L.; LIANG, B.; BISWAS, D. K.; MORRISON, M. J.; MCLAUGHLIN, N. B. The carbon footprint of maize production as affected by nitrogen fertilizer and maizelegume rotations. Nutrient Cycling in Agroecosystem, v. 94 , n. 1, p. 15-31, 2012. DOI: 10.1007/s10705-0129522-0

MA, B. L.; WU, T. Y.; TREMBLAY, N.; DEEN, W.; MCLAUGHLIN, N. B.; MORRISON, M. J.; GREGORICH, E. G.; STEWART, G. Nitrous oxide fluxes from corn fields: On-farm assessment of the amount and timing of nitrogen fertilizer. Global Change Biology, v. 16 , n. 1 , p. $156-170,2010$. DOI: $10.1111 /$ j.13652486.2009.01932.x

MAO, Y. Effects of incorrect rotary tillage operation on soil fertilizer protecting and moisture keeping and yield of wheat. Agriculture Development Equipment, v. 2, n. 1, p. 26-27, 2009.

MITCHELL, J. K.; MCISAAC, G. F.; WALKER, S. E.; HIRSHI, M. C. Nitrate in river and subsurface drainage flows from an east central Illinois watershed. Transactions of the ASABE, v. 432, n. x, p. 337-342, 2000. DOI:10.13031/2013.2709

MOSADDEGHI, M. R.; MORSHEDIZAD, M.; MAHBOUBI, A. A.; DEXTER, A. R.; SCHULIN, R. Laboratory evaluation of a model for soil crumbling for prediction of the optimum soil water content for tillage. Soil and Tillage Research, Amsterdam, v. 105, n. 2, p. 242-250, 2009. DOI: 10.1016/j.still.2009.08.005 
MUTHUKUMAR, V. B.; VELAYUDHAM, K.; THAVAPRAKASH, N. Effect of plant growth regulators and time of nitrogen application on quality and green cob yield of baby corn (Zea mays L.). Madras Agriculture Journal, v. 92, n. 7-9, p. 545-548, 2005.

OFFICIAL METHODS OF ANALYSIS OF THE ASSOCIATION OF OFFICIAL ANALYTICAL CHEMISTS - AOAC. $15^{\text {th }}$ ed. association of Analytical Chemists Incorporation Virginia, 1990. v. 11.

OLESEN, J. E.; MUNKHOLM, L. J. Subsoil loosening in a crop rotation for organic farming eliminated plough pan with mixed effects on crop yield. Soil and Tillage Research, Amsterdam, v. 94, n. 2, p. 376-385, 2007. DOI: $10.1016 /$ j.still.2006.08.015

SHARMA, P.; ABROL, V.; SHARMA, R. K. Impact of tillage and mulch management on economics energy requirement and crop performance in maize-wheat rotation in rainfed subhumid inceptisols, India. European Journal of Agronomy, v. 34, n. 1, p. 46-51, 2011. DOI: 10.1016/j.eja.2010.10.003

SILVA, P. R. F.; STRIEDER, M. L.; COSER, R. P. S.; RAMBO, L.; SANGOI, L.; ARGENTA, G.; FORSTHOFER, E. L.; SILVA, A. A. Grain yield and crude protein content increase of maize hybrids with late nitrogen side-dressing. Scientia Agricola, Piracicaba, v. 62 , n. 5, p. 487-492, 2005. DOI: 10.1590/S010390162005000500014

STEEL, R. G. D.; TORRIE, J. H.; DICKEY, D. A. Principles and procedures of statistics. A biometrical approach. New York: McGraw Hill Book Co., 1997. 666 p.

SUN, X.; DING, Z.; WANG, X.; HOU, H.; ZHOU, B.; YUE, Y. Subsoiling practices change root distribution and increase post-anthesis dry matter accumulation and yield in summer maize. PLoS ONE, San Francisco, v. 12, n. 4, p. e0174952, 2017. DOI: 10.1371/journal.pone.0174952

TURNBULL, T. L.; KELLY, N.; ADAMS, M. A.; WARREN, C. R. Within-canopy nitrogen and photosynthetic gradients are unaffected by soil fertility in field-grown Eucalyptus globulus. Tree Physiology, v. 27 , n. 11, p. 1607-1617, 2007. DOI: 10.1093/ treephys/27.11.1607

URIBELARREA, M.; CRAFTS-BRANDNER, S. J.; BELOW, F. E. Physiological N response of fieldgrown maize hybrids (Zea mays L.) with divergent yield potential and grain protein concentration. Plant and Soil, The Hague, v. 316, p. 151-160, 2009. DOI: 10.1007/ s11104-008-9767-1

VANYINE, A. S.; TÓTH, B.; NAGY, J. Effect of nitrogen doses on the chlorophyll concentration, yield and protein content of different genotype maize hybrids in Hungary. African Journal of Agricultural Research, v. 7, n. 16, p. 2546-2552, 2012. DOI: 10.5897/AJAR11.979

VILLAMIL, M. B.; NAFZIGER, D. E. Corn residue, tillage, and nitrogen rate effects on soil carbon and nutrient stocks in Illinois. Geoderma, Amsterdam, v. 253-254, n. 1, p. 61-66, 2015. DOI: 10.1016/j.geoderma.2015.04.002

VITA, P. D.; PAOLO, E. D.; FECONDO, G.; FONZO, N. D.; PISANTED, M. No tillage and conventional tillage effects on durum wheat yield, grain quality and soil moisture content in southern Italy. Soil and Tillage Research, Amsterdam, v. 92, n. 1-2, p. 69-78, 2007. DOI: 10.1016/j.still.2006.01.012

WANG, Y.; CHEN, Y.; RAHMAN, S.; FROESE, J. Tillage effects on soil penetration resistance and early crop growth for Red River clay. Canadian Biosystem Engineering, v. 51, p. 1-11, 2009.

WASAYA, A.; TAHIR, M.; ALI, H.; HUSSAINA, M.; YASIR, T. A.; SHER, A.; IJAZ, M.; SATTAR, A. Influence of varying tillage systems and nitrogen application on crop allometry, chlorophyll contents, biomass production and net returns of maize (Zea mays L.). Soil and Tillage Research, Amsterdam, v. 170, n. 1, p. 18-26, 2017a. DOI: 10.1016/j.still.2017.02.006

WASAYA, A.; TAHIR, M.; TANVEER, A.; YASEEN, M. Response of maize to tillage and nitrogen management. Journal of Animal and Plant Sciences, v. 22, n. 2, p. 452456, 2012.

WASAYA, A.; TAHIR, M.; YASIR, T. A.; AATIF, H. M.; SHAHZAD, U. Response of maize (Zea mays L.) to different tillage regimes and nitrogen timings under semiarid irrigated conditions. Pakistan Journal of Agriculture Sciences, v. 54, n. 3, p. 553-560, 2017b. DOI: 10.21162/ PAKJAS/17.1729

WASAYA, A.; TAHIR, M.; YASIR, T. A.; AKRAM, M.; FAROOQ, O.; SARWAR, N. Soil physical properties, nitrogen uptake and grain quality of maize (Zea mays L.) as affected by tillage systems and nitrogen application. Italian Journal of Agronomy, v. 13, n. 4, p. 324-331, 2018b. DOI: 10.4081/ija.2018.1197

WASAYA, A.; TAHIR, M.; YASIR, T. A.; ALLAH, S.; HUSSAIN, M. Impact of tillage systems and temporal nitrogen application on soil properties, nitrogen uptake and net returns in maize. International Journal of Agriculture and Biology, v. 20, n. 9, p. 1953-1960, 2018a. DOI: $10.17957 / \mathrm{IJAB} / 15.0714$

YUSUF, D. D. Effect of variation in tillage systems on maize (Zea mays L.) establishment and grain yield in a semi-arid tropical climate. Journal of Agriculture Science and Technology, v. 8, n. 1, p. 171-179, 2006. 
